\title{
PENJERAPAN ZAT WARNA SINTETIS MENGGUNAKAN KARBON AKTIF KELAPA SAWIT DAN PENGEMBANGANNYA SEBAGAI BAHAN AJAR
}

\author{
(Synthetic Color Clinic Applications Using Activated Carbon Palm Oil \\ and Its Development as Air Seeds)
}

\author{
Efa Susanti $^{1 *}$, M.Lutfi Firdaus ${ }^{2}$, Sumpono ${ }^{2}$ \\ ${ }^{1}$ Mahasiswa S-2 Pendidikan IPA FKIP Universitas Bengkulu \\ ${ }^{2}$ Dosen S-2 Pendidikan IPA FKIP Universitas Bengkulu \\ *Email : efasusanti09@gmail.com
}

\begin{abstract}
This study aims to: (1) explain the ability of the active carbon absorption of Palm Oil Palm as a dye adsorbent Reactive Red and Direct Green (2) determines the $\mathrm{pH}$, contact time, and weight of the optimum adsorbent and the influence of temperature using activated carbon. Reactive Red and Direct Green dyestuffs. (3) to explain the influence of video media usage on the improvement of learning result and critical thinking ability of students in Chemistry class XI MIPA E at SMAN 2 Kota Bengkulu. The procedure in this study is the activation of activated carbon of palm oil and activated, activated carbon characterization using FTIR, Determination of maximum wavelength $(\lambda)$, Calibration curve creation, Adsorption of substance by activated carbon of palm oil: determining $\mathrm{pH}$, contact time, adsorbent weight, , adsorption isotherms, Determination of temperature effect, Adsorption Isotherm Determination, Determination of adsorption kinetics, Applications on dyestuffs. The data were analyzed. The result of $\mathrm{pH}$ variation, variation of adsorbent weight, and contact time were made curve so that $\mathrm{pH}$, adsorbent weight, concentration and optimum contact time were obtained using Excel program. Using ANAVA one way, followed by KR-20 test and one sample $t$ test. The results showed that there were: reactive red optimum wavelength $496 \mathrm{~nm}$, optimum $\mathrm{pH}$ 3, optimum time $40 \mathrm{~min}$, absorbent weight $150 \mathrm{mg}$, maximum absorbency KAPKS $32,73 \mathrm{mg} / \mathrm{gr}$ and direct green optimum wavelength $613 \mathrm{~nm}$, with optimum pH 5, optimum time 40 minutes, absorbent weight 150 $\mathrm{mg}$, maximum absorbency KAPKS $32.825 \mathrm{mg} / \mathrm{gr}$. there is an increase of chemistry learning outcomes during the enrichment hours or outside of class hours and critical thinking skills of grade XI IPA E SMAN2 Kota Bengkulu using audio-visual media with average pretest score of 75 and average post test score 82.27 with four criteria critical thinking skills are less critical by $26 \%$, critical enough $43 \%$, critical $23 \%$ and very critical at $8 \%$.
\end{abstract}

Keywords: adsorption, dyestuff, synthetic, activated carbon, palm oil, teaching materials.

\begin{abstract}
ABSTRAK
Penelitian ini bertujuan untuk: (1)menjelaskan kemampuan daya serap karbon aktif Pelepah Kelapa Sawit sebagai adsorben zat warna Reactive Red dan Direct Green (2) menentukan $\mathrm{pH}$, waktu kontak, dan berat adsorben optimum serta pengaruh suhu mengunakan karbon aktif Pelepah Kelapa Sawit dalam menyerap zat warna Reactive Red dan Direct Green. (3) menjelaskan pengaruh penggunaan media video terhadap peningkatan hasil belajar dan kemampuan berpikir kritis siswa pada pelajaran Kimia kelas XI MIPA E di SMAN 2 Kota Bengkulu. Prosedur pada penelitian ini pembuatan karbon aktif pelepah kelapa sawit dan diaktivasi, karakterisasi karbon aktif menggunakan FTIR, Penentuan panjang gelombang maksimum $(\lambda)$, Pembuatan kurva kalibrasi, Adsorbsi zat oleh karbon aktif pelepah kelapa sawit: menentukan $\mathrm{pH}$, waktu kontak, berat adsorben, suhu, isoterm adsorbsi, Penentuan pengaruh suhu, Penentuan isoterm Adsorpsi, Penentuan kinetika adsorpsi, Aplikasi pada zat warna. Data penelitian dianalisis Data
\end{abstract}


hasil variasi $\mathrm{pH}$, variasi berat adsorben, dan waktu kontak dibuat kurva sehingga dapat ditentukan $\mathrm{pH}$, berat adsorben, konsentrasidan waktu kontak optimum dengan menggunakan program Excel.menggunakan ANAVA satu jalan, dilanjutkan uji KR-20 dan uji t satu sampel. Hasil penelitian menunjukkan bahwa terdapat : reactive red panjang gelombang optimum $496 \mathrm{~nm}$, pH optimum 3, waktu optimum 40 menit, berat absorben $150 \mathrm{mg}$, daya serap maksimum KAPKS 32,73 mg/gr dan direct green panjang gelombang optimum $613 \mathrm{~nm}$, dengan pH optimum 5, waktu optimum 40 menit, berat absorben 150 $\mathrm{mg}$, daya serap maksimum KAPKS $32,825 \mathrm{mg} / \mathrm{gr}$. terdapat peningkatan hasil belajar kimia pada jam pengayaan atau di luar jam pelajaran dan kemampuan berpikir kritis siswa kelas XI IPA E SMAN2 Kota Bengkulu menggunakan media audio - visual dengan rata rata nilai pretes 75 dan rata - rata nilai post test 82,27 dengan empat kriteria kemampuan berpikir kritis kurang kritis sebesar $26 \%$, cukup kritis $43 \%$, kritis $23 \%$ dan sangat kritis sebesar $8 \%$.

Kata kunci: penjerapan, zat warna, sintetis, karbon aktif, kelapa sawit, bahan ajar.

\section{PENDAHULUAN}

$\begin{array}{ccc}\text { Di } & \text { Kota } & \text { Bengkulu proses } \\ \text { pembuatan } & \text { batik } & \begin{array}{c}\text { besurek dilakukan } \\ \text { dikn }\end{array}\end{array}$ dibeberapa tempat pembuatan batik. Hal ini menunjuk bahwa banyak limbah zat warna yang di hasilkan oleh industri batik. Limbah tersebut langsung dialirkan ke tempat pembuangan penduduk tanpa ada pengolahan terlebih dahulu. Ini mengakibatkan lingkungan di sekitar industri batik tercemar dan mengakibatkan ekosistem terganggu.

Media pembelajaran digunakan sebagai alat bantu untuk mempermudah dan membantu tugas guru dalam menyampaikan berbagai bahan dan materi pelajaran, serta mengefektifkan dan mengefisienkan siswa dalam memahami materi dan bahan pelajaran tersebut. Pemilihan penggunaan media pembelajaran yang tepat akan membuat siswa dapat belajar dengan mudah dan merasa senang dalam mengikuti pelajaran.

\section{Penelitian dan Pengembangan Research dan Development (R\& D)}

Pengertian

Penelitian

Pengembangan atau Research and Development (R\&D) sering diartikan sebagai suatu proses atau langkahlangkah untuk mengembangkan suatu produk baru atau menyempurnakan produk yang telah ada. Yang dimaksud dengan produk dalam konteks ini adalah tidak selalu berbentuk hardware (buku, modul, alat bantu pembelajaran di kelas dan laboratorium), tetapi bisa juga perangkat lunak (software) seperti program untuk pengolahan data, pembelajaran di kelas, perpustakaan atau laboratorium, ataupun model - model pendidikan, pembelajaran pelatihan, bimbingan, evaluasi, manajemen, dll.

\section{Media Pembelajaran}

Selanjutnya dalam aktivitas pembelajaran, media dapat didefinisikan sebagai sesuatu yang dapat membawa informasi dan pengetahuan dalam Interaksi yang berlangsung antara pendidik dan peserta didik (Fathurrohman \& Sutikno, 2010)

Pendidik haruspandai merancang, menyusun, mengevaluasi, menganalisis hingga merevisi dan mengembangkan media terhadapmateri yang disampaikankepadapesertadidik (Dick and Carey, 2006)

\section{BerpikirKritis}

Salah satu cara mengembangkan keterampilan berpikir kritis adalah dengan melakukanpenilaian berbasis keterampilan berpikir kritis. Tes keterampilan berpikir kritis dapat dikembangkan berdasarkan indikator-indikator keterampilan berpikir kritis.Indikator Keterampilan Berpikir Kritis

Ennis (1985: 55-56) mengklasifikasikan keterampilan berpikir kritis menjadi lima kelompok yang diturunkan menjadi dua belas indikator. 
Adapun indikator yang dikembangkan pada penelitian pengembangan instrumen penilaian ini adalah sebagai berikut:

1. Merumuskan masalah

2. Menganalisis argumen

3. Bertanya dan menjawab pertanyaan

4. Mempertimbangkan sumber apakah dapat dipercaya atau tidak

5. Mengobservasi dan mempertimbangkan laporan observasi

6. Mendefinisikan istilah dan mempertimbangkan suatu definisi

7. Menginduksi dan mempertimbangkan hasil induksi

8. Membuat dan menentukan hasil pertimbangan

9. Mengidentifikasi asumsi-asumsi pembelajaran, oleh karena itu penulis mengambil beberapa indikator yang dianggap mewakili indikator-indikator lainnya. Begitu pula dengan instrumen

10. Menentukan suatu tindakan

11. Memutuskan dan merumuskan

12. Berinteraksi dengan orang lain

\section{Hasil Belajar}

Hasil pembelajaran merupakan suatu gambaran dari penguasaan siswa terhadap kegiatan pembelajaran yang dilakukan guru sebagai pengajar. Dengan kata lain hasil pembelajaran merupakan suatu prestasi yang ingin dicapai siswa setelah mengikuti proses pembelajaran, sedangkan hakikat dari proses pembelajaran adalah terjadinya suatu proses yang dapat mengubah tingkah laku dalam diri siswa.

\section{METODE}

\section{Aplikasi Adsorben Pada Limbah}

Limbah cair zat warna merupakan limbah buatan (artifisial) dengan mencampurkan zat warna Reactivered dan Directgreen. Konsentrasi awal zat warna diukur setelah zat warna diatur $\mathrm{pH}$ sampai $\mathrm{pH}$ optimum dengan penambahan $\mathrm{HCl}$ dan $\mathrm{NaOH}$. Ditambahkan arang aktif dengan berat optimum ke dalam $10 \mathrm{~mL}$ limbah, kemudian diaduk dengan shakerpada 150 rpm selama waktu kontak optimum. Kemudian ditentukan konsentrasi filtrat yang diperoleh dengan spektofotometer UV
- Vis untuk mengetahui konsentrasi yang tidak terserap oleh arang aktif. Konsentrasi limbah zat warna yang diserap oleh arang aktif pelepah kelapa sawit adalah selisih antara konsentrasi awal larutan dengan konsentrasi yang tidak diserap (Agustry, 2016).

\section{Penelitian pendidikan}

Penelitian ini dilakukan di luar jam pelajaran atau kelas pengayaan. Pembelajaran diluar jam pelajaran ini dilakukan pada siswa kelas XI MIPA E SMAN 2 Kota Bengkulu. Sebelum dilakukan penelitian siswa diberikan pretest lalu siswa diberikan pembelajaran yang menggunakan media video yang dijadikan sebagai bahan ajar. Dan setelah selesai siswa diberikan postest. Penelitian dilakukan juga dengan membagi kelompok - kelompok untuk diskusi dan mempersentasikannya. Kemudian siswa kembali mengerjakan soal yang berbentuk soal uraian yang bertujuan untuk melihat keterampilan berpikir siswa yaitu siswa berpikir kritis.

\section{HASIL DAN PEMBAHASAN}

\section{Aplikasi Adsorben Pada Limbah Zat Warna}

KAPKS sebagai adsorben zat warna diaplikasikan kepada limbah cair artificial yang mengandung zat warna Reactive Red dan Direct Green. Pembuatan limbah artifisial dilakukan dengan mencampurkan kedua zat warna, masing-masing konsentrasinya 500 ppm dengan volume tertentu (tidak diketahui). Proses adsorpsi dilakukan pada kondisi optimum setiap zat warna dimana untuk analisis limbah zat warna Reactive Red dilakukan pada $\mathrm{pH} 3$ dan waktu kontak 40 menit. Sedangkan untuk zat warna Direct Green dilakukan pada $\mathrm{pH} 5$ dan waktu kontak 40 menit. Kedua zat warna ditambahkan KAPKS sesuai dengan berat optimumnya. Konsentrasi zat warna sebelum dan setelah adsorpsi diukur dengan spektofotometer UV-VIS. 
Tabel Data Hasil Adsorpsi Limbah Zat Warna RR 120 Dan DG 26 terhadap Karbon Aktif Pelepah Kelapa Sawit

\begin{tabular}{|l|r|l|l|l|l|r|r|r|}
\hline $\begin{array}{l}\text { zat } \\
\text { warna }\end{array}$ & Ph & $\begin{array}{l}\text { abs } \\
\text { awal }\end{array}$ & $\begin{array}{l}\text { abs } \\
\text { Akhir }\end{array}$ & $\begin{array}{l}\text { C } \\
\text { awal } \\
\text { (ppm) }\end{array}$ & $\begin{array}{l}\text { C } \\
\text { terserap }\end{array}$ & $\begin{array}{l}\text { C } \\
\text { Akhir } \\
(\mathrm{ppm})\end{array}$ & $\begin{array}{l}\text { Q } \\
(\mathrm{mg} / \mathrm{g})\end{array}$ & $\begin{array}{l}\text { Efisiensi } \\
(\%)\end{array}$ \\
\hline RR 120 & 3 & 1,229 & 0,042 & 500 & 490,944 & 9,056 & 32,73 & 98 \\
\hline DG 26 & 5 & 0,941 & 0,039 & 500 & 492,38 & 7,62 & 32,825 & 98,4 \\
\hline
\end{tabular}

\section{Penelitian Pembelajaran}

Hasil dari penelitian laboratorium akan di implementasikan dalam pembelajaran. Pada penelitian ini, hasil penelitian tersebut di kemas dalam bentuk sumber belajar yaitu media video. Media video ini diterapkan pada pembelajaran Kimia kinetika untuk siswa SMA N 2 Kota Bengkulu kelas XI MIPA E di luar jam pembelajaran atau pada jam pengayaan. Jenis penelitian pembelajaran yang dilakukan pada penelitian ini menggunakan pendekatan research and development ( $\mathrm{R} \& \mathrm{D}$ ). Dari hasil penelitian diperoleh

\section{Uji Panelis Instrumen Video audio - visual}

Tabel 4.7. Hasil interclass coefficient corelation (ICC) instrument Video

\begin{tabular}{|c|c|c|c|c|}
\hline SV & JK & Db & Variansi & ICC \\
\hline Penilai & 0,0985 & 3 & 0,016 & \\
\hline Butir & 13,3125 & 27 & 0,112 & \\
\hline Error & 3,6525 & 81 & 0,0451 & 0,65 \\
\hline
\end{tabular}

Dari data diatas didapatkan nilai dengan kategori video baik digunakan reliabilitas antar panelis cukup memuaskan yaitu sebesar 0,65

\section{Uji Panelis Instrumen Test}

Tabel 4.8. Hasil interclass coefficient corelation (ICC) instrument Test

\begin{tabular}{|c|c|c|c|c|}
\hline SV & JK & Db & Variansi & ICC \\
\hline Penilai & 0,0333 & 2 & 0,0125 & \\
\hline Butir & 5,0666 & 19 & 0,0833 & \\
\hline Error & 0,6334 & 38 & 0,01667 & 0,741 \\
\hline
\end{tabular}

Hasil uji ICC menunjukkan harga ICC sebesar 0,741. Butir soal dikatakan reliabel jika nilai ICC $\geq 0,600$ (Murti, 2011). Jadi disimpulkan bahwa butir soal yang divalidasi oleh tiga panelis dinyatakan dapat digunakan dalam uji coba butir test.

\section{Uji Reliabilitas Instrumen}

Reliabilitas adalah taraf sampai dimana suatu tes mampu menunjukkan suatu konsistensi hasil pengukuran yang ditunjukkan dalam taraf ketepatan dan ketelitan hasil pengukuran (Winarni, 2011). Hasil uji reliabilitas butir tes diperoleh sebesar 0,7999. Data ini menunjukkan bahwa reliabiitas instrument berada pada taraf tinggi, artinya ketepatan dan ketelitian instrument tes dapat dipercaya (Arikunto, 2009).

\begin{tabular}{|c|c|c|c|c|c|}
\hline SV & JK & db & Variansi & ICC & r11 \\
\hline Penilai & 0,3333 & 2 & 0,0125 & & \\
\hline Butir & 5,0666 & 19 & 0,0833 & & \\
\hline Error & 0,6334 & 38 & 0,01667 & 0,741 & 0,7999 \\
\hline
\end{tabular}


Karena $r 11=0,7999>0,7$ maka tes dikatakan reliabel atau tes dapat dipercaya

\section{Uji normalitas}

Uji normalitas yang dilakukan menggunakan uji kolmogorov-smirnov. Hasil uji normalitas yang dilakukan antara pretest dan posttest disajikan pada tabel 4.12. Berdasarkan hasil uji normalitas Kolmogorov-Smirnov diketahui bahwa signifikansi pretest sebesar 9,169 dengan nilai derajat kebebasan $(\mathrm{dk})=34$ dengan taraf signifikan 5\% maka diperoleh hasil 11,070. Karena uji normalitas hitung lebih kecil dari uji normalitas tabel, maka dapat disimpulkan bahwa hasil pretes dan postes berdistribusi normal.

\section{Implementasi Media Audio visual} dalam Pembelajaran

Implementasi penelitian sains

dalam pembelajaran kimia bertujuan

untuk mengetahui perbedaan hasil TABEL NILAI PRETEST DAN POSTEST

\begin{tabular}{|l|l|l|l|}
\hline $\begin{array}{l}\text { NILAI } \\
\text { PRETEST }\end{array}$ & FREKUENSI & $\begin{array}{c}\text { NILAI } \\
\text { POSTTEST }\end{array}$ & FREKUENSI \\
\hline $50-56$ & 1 & $50-56$ & 0 \\
\hline $57-63$ & 2 & $57-63$ & 1 \\
\hline $63-79$ & 19 & $63-79$ & 2 \\
\hline $80-86$ & 11 & $80-86$ & 20 \\
\hline $87-93$ & 2 & $87-93$ & 7 \\
\hline $94-100$ & 0 & $94-100$ & 5 \\
\hline
\end{tabular}

Berdasarkan hasil pretest tersebut diketahui rata-rata pre test belajar pada aspek koqnitif dan berpikir kritis siswa pada jam pengayaan. Ini bertujuan agar siswa dapat melihat secara langsung cara menggunakan karbon aktif dari pelepah kelapa sawit dapat mengadsorpsi zat warna.

\section{Hasil Kognitif Belajar Siswa}

Sebelum pembelajaran dilaksanakan pada jam pengayaan, siswa-siswi diberikan tes awal (pretes) dan setelah dilakukan pembelajaran menggunakan media audio visual dengan diberikan penjelasan penjelasan siswa diberikan tes akhir (posttes). Lalu siswa diberi kesempetan untuk berdiskusi tentang penerapan karbon aktif pelepah kelapa sawit dapat mengadsorpsi zat warna ini, setelah itu diberikan kembali soal uraian yang bertujuan melihat berpikir kritis siswa kelas XI IPA E di SMA N 2 KotaBengkulu.

yaitu 75 dengan skor terendah 60, skor tertinggi 90 , serta nilai terbanyak yang diperoleh siswa berkisar pada interval nilai 71-80.

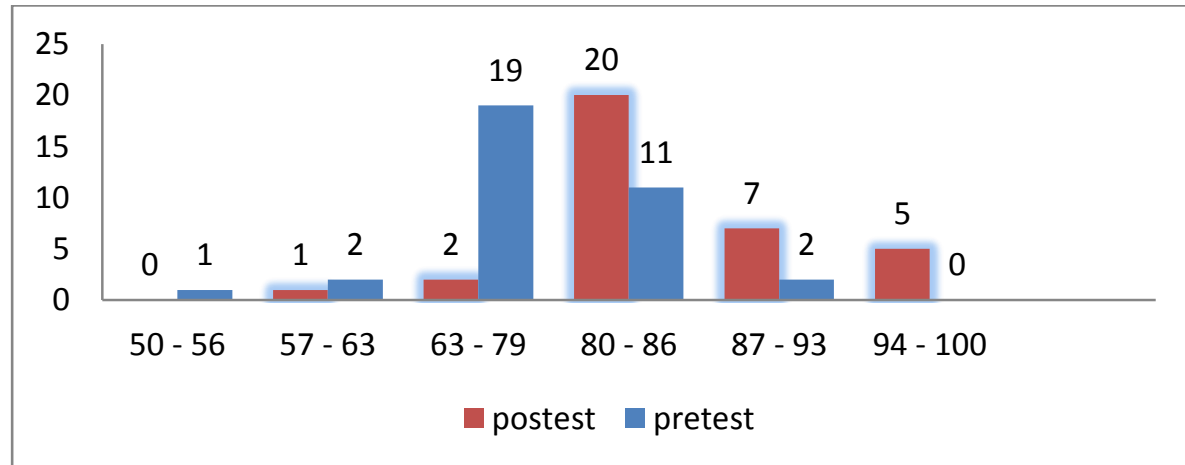

gambar 4.16. Histogram Hasil Pretest dan Posttest Siswa 
Hasil nilai postest, diperoleh rata-rata nilai 82,71 dengan nilai terbanyak antara 81 samapai 85 . Dari hasil pre test dan post tes siswa dapat disimpulkan bahwa pengaruh media audio visual dalam pembelajaran sangatlah berpengaruh atau dapat meningkatkan hasil belajar siswa dilihat dari hasil belajar siswa.

\section{Hasil Belajar Berpikir Kritis Siswa}

Berpikirk ritis adalah cara berpikir seseorang mengenai suatu masalah dimana pemikir meningkatkan kualitas pemikirannya dengan menangani secara terampil struktur-struktur yang melekat dalam pemikiran dan menerapkan standar-standar intelektual padanya
(Nitko, A.J \& Brookhart, 2007). Dengan kata lain, berpikir kritis merupakan proses mental yang terorganisasi dengan baik dan berperan dalam proses mengambil keputusan untuk memecahkan masalah dengan menganalisis dan menginterpretasi data dalam kegiatan inkuiri ilmiah. Ennis mengungkapkan bahwa berpikir kritis adalah pemikiran yang masuk akal dan reflektif yang berfokus untuk memutuskan apa yang mesti dipercaya atau dilakukan (Fisher, 2009: 4).

Dari indikator - indikator di atas hanya beberapa indikator saja yang digunakan. Dari hasil penilaian evaluasi di kelas XI IPA E yang berjumlah 35 siswa diperoleh nilai sebagai berikut:

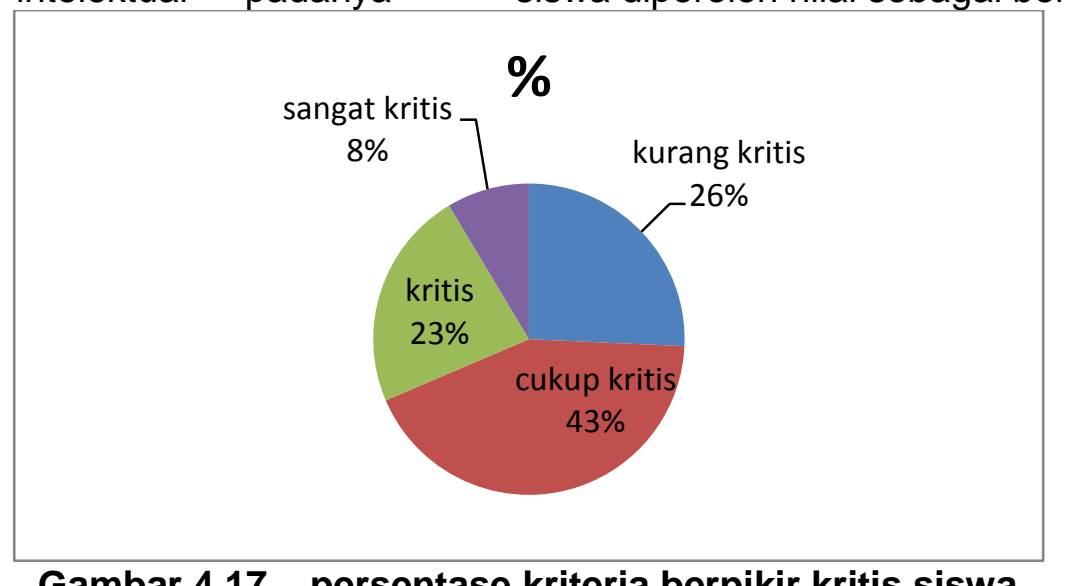

\section{Gambar 4.17 persentase kriteria berpikir kritis siswa}

Dari gambar 4.17. dengan jumlah siswa sebanyak 35 siswa dengan nilai 70 sebanyak $26 \%$ siswa berpikir kurang kritis, nilai 80 sebanyak $43 \%$ siswa berpikir cukup kritis, nilai 90 sebanyak $23 \%$ siswa berpikir kritis dan nilai 100 sebanyak $8 \%$ siswa berpikir sangat kritis.

\section{KESIMPULAN}

Berdasarkan hasil penelitian yang didapatkan, maka dapat disimpulkan bahwa :

1) Daya serap maksimum (Qmax) karbon aktif pelepah kelapa sawit terhadap zat warna reactive red 120 dan direct green 26 adalah berturut - turut sebesar 32,73 $\mathrm{mg} / \mathrm{gr}$ dan $32,825 \mathrm{mg} / \mathrm{gr}$.

2) Terdapat peningkatan hasil belajar kimia menggunakan media Audio Visual pada jam pengayaan atau diluar jam pelajaran yang dapat dilihat dari rata- rata nilai pretes sebesar 75,00 dan nilai postes sebesar 82,29 dan Instrumen penilaian berbentuk tes esai untuk menilai kemampuan berpikir kritis siswa di dapat empat kriteria yaitu kurang kritis sebesar $26 \%$, cukup kritis $43 \%$, kritis $23 \%$ dan sangat kritis sebesar $8 \%$.

\section{DAFTAR PUSTAKA}

Atkins P.W. 1997. Kimia Fisika Jilid 2. Erlangga: Jakarta

Arikunto, S. 2008. Prosedur Penelitian Suatu Pendekatan Praktek. Jakarta: Rineka Cipta.

Arsyad, Azhari. 2006. Media Pembelajaran. PT. RajaGrafindo Persada.Jakarta

Dick. W \& Carey. 2006. The Systematic design of Instruction. New Jersey Columbus, Ohio: Pearson 
Fassenden, R.J., Fasenden, J.S. 1992.

Kimia Organik Edisi ketiga jilid 2.

Erlangga: Jakarta.

Gunawan, S. G. 2007,

FarmakologidanTerapi, FKUI. Jakarta

Hawadi, dkk. 2001. Psikologi

Perkembangan Anak (Mengenal

Sifat, Bakat dan Kemampuan

Anak). Grasindo

Hendayana, S. 1994. Kimia Analitik

Instrumen Edisi Kesatu.

Semarang: IKIP Semarang Press

Kusnaedi. 2010. Mengelola Air kotor untuk air minum. Jakarta: Penebar

Swadaya

Linsley, R.K dan Franzni, J.B. 1991. Teknik Sumber Daya Air Edisi Ketiga. Jakarta: Erlangga

Muna, N. 2014. Adsorpsi zat warna malichite Green (MG) olek Komposit Kitosan Bentonit. Tesis.

Program Studi Kimia Fakultas Sains dan Teknologi UII Sunan Kalijaga

Mulyasa, 2006. menciptakan pembelajaran kreatif dan menyenangkan . Bandung : Remaja Rosdakarya

Ong and Borich. 2006, Teaching Strategies that Promote Thinking: Models and Curriculum Approaches. McGraw-Hill 